\title{
Policy relevance of the health expectancy indicator; an inventory in European Union countries
}

\author{
Harry P.A. van de Water*, Rom J.M. Perenboom, \\ Hendriek C. Boshuizen
}

TNO Prevention and Health, P.O. Box 2215, 2301 CE Leiden, The Netherlands

Received 30 November 1995; accepted 20 December 1995

\begin{abstract}
Due to epidemiological transitions in population health both an increase in life expectancy and in chronic morbidity and disability have been observed in many countries. Consequently the tension between 'living longer' on the one hand and the 'quality of life' on the other has become a central health policy problem. The introduction of the indicator 'health expectancy' (HE), a measurement that combines mortality data with morbidity and disability data, was a logical reaction to these changes and to the growing need for a present-day yardstick to estimate this problem. The HE indicator is still under development, a process being furthered by the international network of researchers, REVES. A European project, called Euro-REVES, aims to promote and harmonize future HE calculations in Europe. To begin this project and to gain more insight into the indicator's policy relevance, an inventory has been carried out among policy makers, National Statistical Institutes and researchers in countries of the European Union (EU). This paper presents the results of the inventory, attempts to place these within a provisional classification system of HE types, and discusses the consequences of the findings for further conceptual harmonization and development of the indicator. Already 11 of the $15 \mathrm{EU}$ member states have $\mathrm{HE}$ results available. The actual use of such results for policy making is increasing. Notwithstanding a great diversity in sources and questions used for the calculations, there seems to be enough similarity to give the harmonization effort a good perspective.
\end{abstract}

Keywords: European Union; Harmonization; Health expectancy; Health indicator; Health measurement; Health policy; Inventory; Policy relevance

* Corresponding author.

0168-8510/96/\$15.00 (C) 1996 Elsevier Science Ireland Ltd. All rights reserved

PII S0168-8510(95)00803-2 


\section{Introduction.}

This article presents the results of an inventory in the 15 member states of the European Union (EU) into the use of a relatively new measure of population health, called 'health expectancy' (HE). The inventory aimed to gain more insight into the policy relevance of this indicator by describing where and how HEs have been calculated and whether and how these calculations have been used by policy makers. It also tries to organize the results into a provisional classification system for different types of HE calculations.

\section{Background.}

\subsection{Changes in population health}

In human communication, man has always used 'measurements' to explain what size or amount he had in mind. In general, therefore, measurements can be seen as tools for achieving timely reflections of relevant phenomena. As the word timely implies, they are not everlasting entities. Measurements come, flower and go depending upon practical applicability. For instance, nowadays nobody would consider the number of swords and horses useful indicators of an army's strength, but they were adequate expressions of this in Medieval times. New measurements of military power have superseded the old ones.

Similar developments can be observed in health policy making. In developed countries, for instance, measurements of mortality - for a long time traditional indicators of population health - are losing their impact due to major changes in the health of populations. These changes, the so-called epidemiological transitions, have resulted in both an increase in life expectancy and an increasc in chronic morbidity and disability [1,2]. Consequently the conflict between 'living longer' on the one hand and 'living in less good health during the extra years gained' on the other has become a central health policy problem. The introduction of a new measurement of population health, the $\mathrm{HE}$ indicator, therefore was no more and no less than a logical response to these changes in population health and to the growing need for policy makers to have a new and contemporary yardstick for adequately estimating this problem [3].

The advantage of the HE indicator is that it combines information about mortality with morbidity and disability data [4]. Although the idea for such an integral indicator dates back to the $60 \mathrm{~s}$, it is only since the mid- 80 s that a substantial number of researchers from different countries have begun to apply the idea [5]. Up to now HE calculations have been made in 37 countries [6]. 


\subsection{International effort}

Most researchers on the HE topic are united in REVES, the International Network on Health Expectancy and the Disability Process, that started in 1989 [5,7-9]. Four countries from Europe (England and Wales, France, the Netherlands and Switzerland) participated in the first meeting of this global network. Since autumn 1994 there is also a European network on health expectancy: EuroREVES $^{1}$. Its goals are to promote and harmonize HE calculations in Europe $[10,11]$. The Euro-REVES subcommittee on Policy Relevance and Conceptual Harmonization aims to clarify the policy relevance of the indicator; recommend which HE types, underlying questions and sources can be used for comparable calculations; and share the knowledge and experience achieved within the EU and the other European countries [10,12]. The first meeting of Euro-REVES in Leiden in June 1995 was the direct reason that an inventory among member states of the EU was made [13]. The goal of it was fourfold: (1) to describe the state of the art in the EU with respect to $\mathrm{HE}$ calculations and the use of its results by policy makers; (2) to see what can be learned from each other's experience; (3) to facilitate the networking process; and (4) to find out to what extent different HE types as distinguished within a provisional classification system were calculated by the different countries.

\subsection{Provisional classification system}

In order to bring more structure into the process of international comparison of the results of calculations, a classification system for different types of HE results has been proposed [14]. An improved version of this system is described in a report written as a contribution to the preparations of the World Health Report 1995 published by the World Health Organization [6]. The classification system - which in its complete form is more detailed than will be explained here - is a step forwards towards better comparability, but many problems still remain to be solved. For this reason, the system is considered 'provisional'.

According to the classification system, HE is a general term for all types of indicators that measure the expected number of life years in a given state of health. The provisional classification system has four groups of HE types. The first group, concerning life years with or without disease, follows the ICD-framework [15]. The second follows the ICIDH framework and has three subgroups [16], respectively life years with or without impairments, disabilities and handicaps. The third is a

\footnotetext{
${ }^{1}$ This research is part of the Euro-REVES project carried out within the framework of the BIOMED II programme of the European Union. The first author is coordinator of the Euro-REVES subcommittee Policy Relevance and Conceptual Harmonization. The two other subcommittees of Euro-REVES are: Mental Health (coordinators Karen Ritchie, INSERM, Montpellier, France and Carol Jagger, University of Leicester, UK) and Methodology (coordinator Nicolas Brouard, INED, Paris, France). Overall coordinator of Euro-REVES is Jean-Marie Robine, INSERM, Montpellier, France, who also is the coordinator of the international REVES network.
} 
'subjective' and the fourth a 'weighted' category. The grouping of HE types, their definitions and some remarks can be found in Table 1 .

\section{Material and methods.}

To each of the 15 member states of the EU, written questionnaires were mailed to three respondents: a policy maker, a representative of the National Statistical Institute and the researcher who - according to the information of the EuroREVES and REVES networks - was most intensely involved in HE calculations. Where possible, respondents were selected with the help of 'national teamleaders', that is the persons who are invited to play a coordinating role for their country in the Euro-REVES project. In some cases when candidates for this role were not yet known, they were selected by addressing the National Ministry of Health and/or the National Institute of Statistics. The intake of completed questionnaires stopped at the end of June 1995. In the analysis, the results of an earlier inventory in OECD countries were taken into account [14].

The questionnaires for the three groups of respondents differed, although they contained overlapping questions. The areas covered in the three questionnaires are presented in Table 2. The main items in the questionnaires were the HE calculations as carried out, the sources and questions used for these calculations and the policy relevance and use of the calculations.

\section{Results.}

\subsection{Response}

The response rate was $33 \%$ for policy makers and $80 \%$ for both National Statistical Institutes and researchers. In three countries the questionnaires for statisticians and researchers were answered by the same persons, because the calculations were done at the National Statistical Institute.

\subsection{Calculations made}

Results concerning the calculations as made in the EU are given in Table 3. HE calculations have been made in most EU member countries (73\%). Only in Greece, Ireland, Luxembourg and Portugal were no such calculations carried out. Some calculations for Germany were done by researchers from elsewhere [17,18]. In most countries calculations were done at a national level $(67 \%)$; in half the countries (53\%) also at the regional/local level. Trend calculations were made in nine member states $(60 \%)$, calculations by socio-economic status (SES) in four $(27 \%)$, regional comparisons in five $(33 \%)$ and disease specific calculations in seven countries $(47 \%)$. To complete the European picture it should be mentioned that outside EU countries, HE calculations have been made in Bulgaria, Norway and Switzerland [6]. 


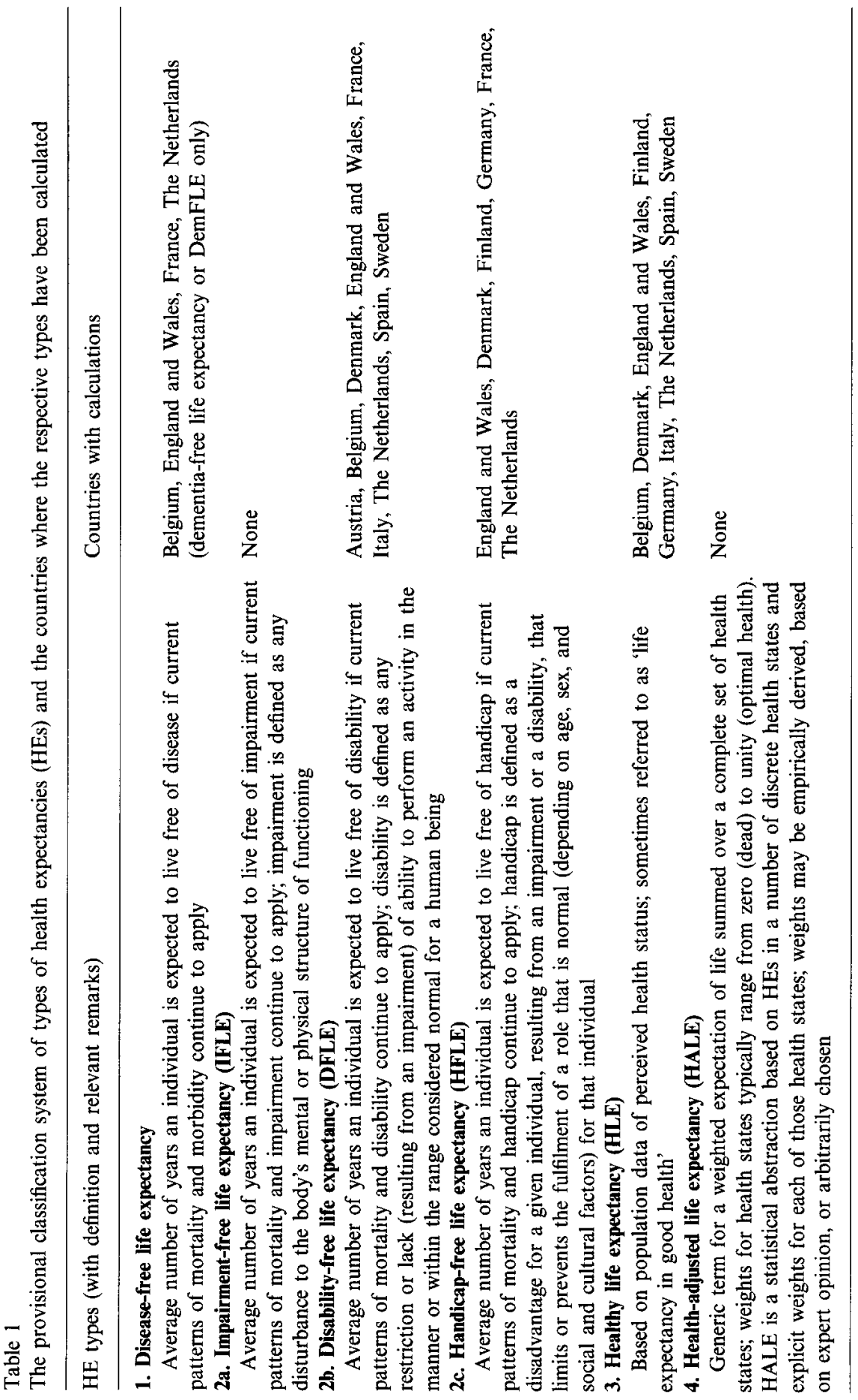




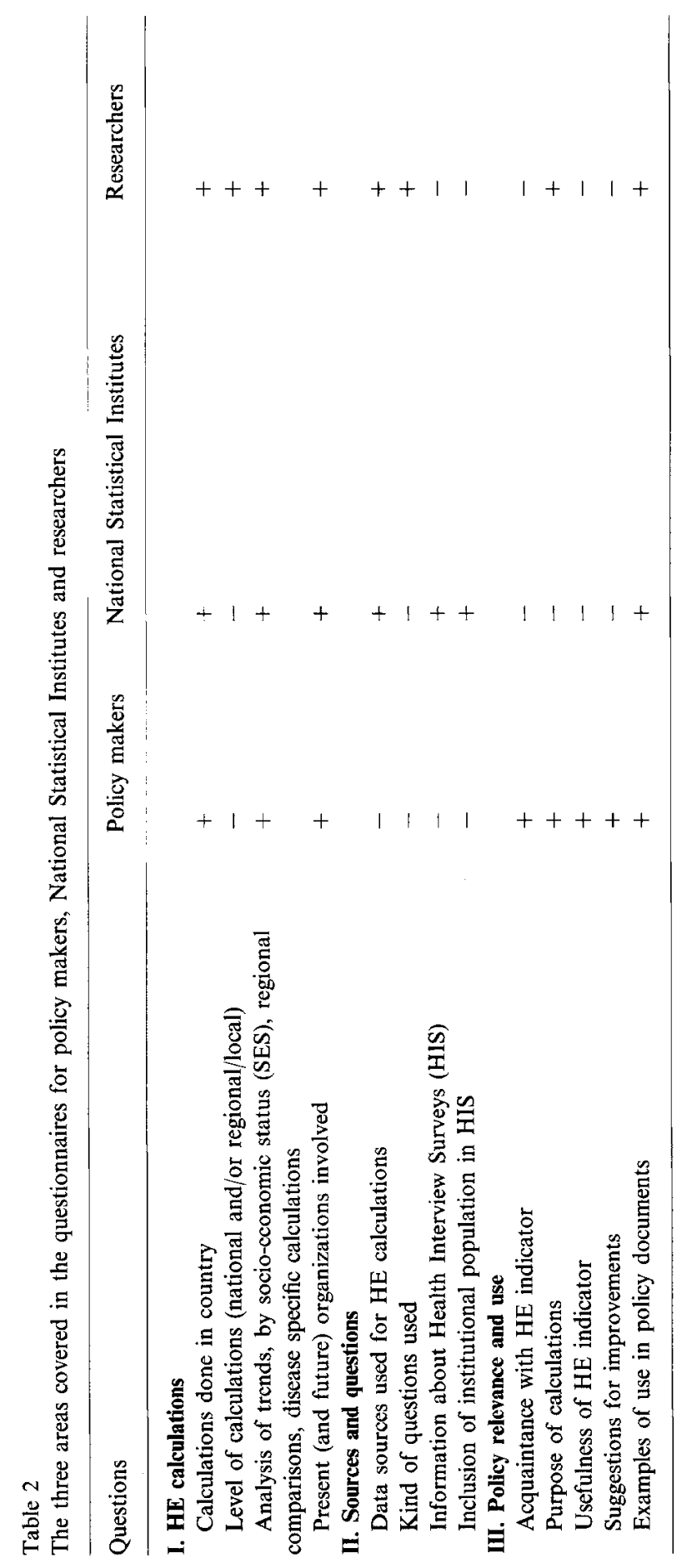




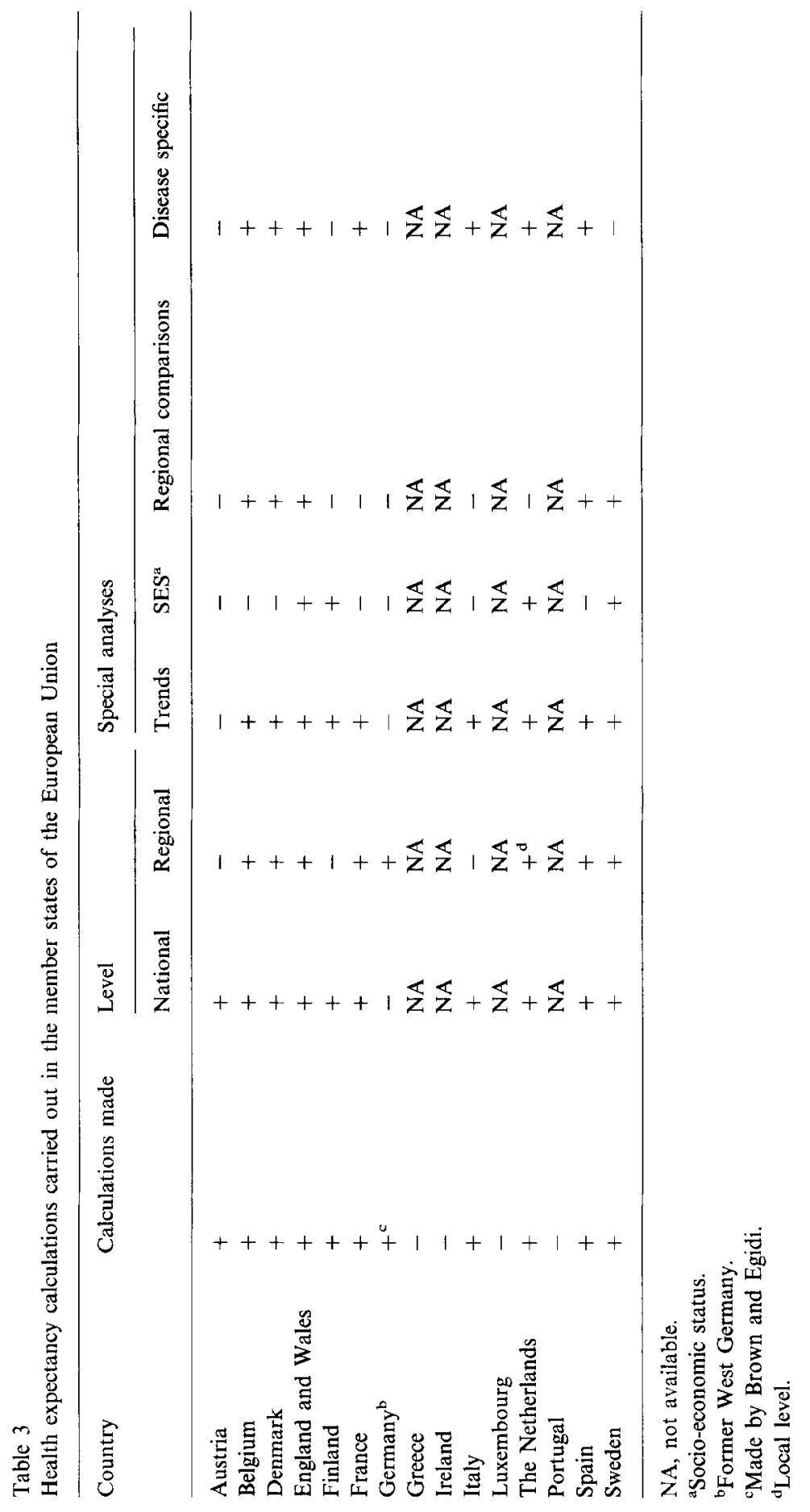




\subsection{Sources and questions used}

To the question of what sources were used or available for HE calculations a wide variety of answers was given: (national) health (or disability) interview surveys, (micro)censuses, national interview surveys (like general household and level of living surveys), morbidity surveys, surveys on ageing, registers (mortality, specific morbidity, institutionalization) and special studies. Also the kind of questions used for the calculations (Table 4) showed a wide variety. Perceived health questions and ADL and/or IADL questions are favourite.

\subsection{Policy relevance and use}

The few policy makers that returned the questionnaires considered $\mathrm{HE}$ a useful or very useful indicator in policy making, but these respondents probably represent a positive selection. The following quotation was a striking remark about the policy relevance: "It's the best way to give a kind of summary of the overall health development".

An interesting question was why the calculations were done. Surprisingly most answers indicated an initiative on the part of the researcher (personal interest, for rcscarch purposcs, for MSC and PhD thesis, epidemiological studies and research). In Denmark, England and Wales, France, The Netherlands, Spain and Sweden, however, there was also much interest on the part of the authorities responsible for health policy. An explanation for this phenomenon could be that in the latter countries researchers had already a couple of years earlier become interested in HE calculations and by now had apparently convinced their policy makers of the usefulness of this indicator. Some other countries seem at present to be in the phase where researchers take an interest in the indicator, a process that very well may be speeded up by the work of Euro-REVES.

Table 4

Kind of questions used for HE calculations

\begin{tabular}{ll}
\hline Kind of question & Used in \\
\hline ADL and/or IADL & Austria, Belgium, Denmark, England and Wales, \\
& Finland, France, Italy, The Netherlands \\
Perceived health & Belgium, Denmark, England and Wales, Finland, \\
& Germany, Italy, The Netherlands, Spain, Sweden \\
Perceived chronic diseases/symptoms & Italy, Spain \\
Limiting (longstanding) illness/disability & Austria, Denmark, England and Wales, Finland, \\
& The Netherlands, Spain, Sweden \\
Other & Belgium, Denmark, England and Wales, France, \\
& Germany, The Netherlands, Spain
\end{tabular}


Some support for the above mentioned explanation - countries in different stages of taking up - can also be found in the answers to the question (to National Statistical Institutes and researchers) 'Could you mention some examples of the use of results of HE calculations in policy documents?'

(1) In Denmark, the 'Public health, health behaviour, prevention programme' (1991) and 'Health promotion programme of the government of Denmark' (1992) - politically accepted for implementation in 1988 - are to a large extent based on the results of HE research [19,20]. Those results also initiated ideas for the prevention of musculoskeletal diseases in Denmark [21].

(2) In England and Wales, HE research has begun to attract the attention of policy makers with a recent review report called 'Health Expectancy and its Uses' [22]. Consequently $\mathrm{HE}$ is being considered as an indicator for 'Health of the Nation' targets and for resource allocation, although it is not yet mentioned in published policy documents.

(3) In France, the HE indicator has achieved an important position in a report of the High Commission on Public Health, a body formally advising the Minister of Health in policy matters. This report 'Health in France' (1994) describes the state of health of the French population and acknowledges that an indicator like HE has until now been badly missed [23].

(4) In the Netherlands, HE was an important key issue in the Public Health Status and Forecasts report that was published in 1993 [24-27]. In the reaction to this document, the formal policy memorandum 'Healthy and Sound', HE gets a central position. 'Increasing the HE' is the first of three main targets for the Dutch health policy 1995-1998 [28]. The results of a study into socio-economic differentials in $\operatorname{HE}[29,30]$ became a major argument in keeping 'diminishing socio-economic inequalities in health' as a priority and prolonging the special research programme on this issue by 5 years.

(5) In Spain, in the framework of the World Health Organization's 'Health For All by the year 2000' strategy, a health plan was published in the Catalan Region in 1991 and in the Basque Country in 1994 [31-35]. For both plans disability-free life expectancy (DFLE) was chosen as one of the health indicators. The Spanish Ministry of Health and Consumption recently published a report with the $\mathrm{HE}$ results from Spain [36].

(6) Finally, in Sweden HE results are used as important background information for considerations about health and intersectoral policies, as can be inferred from the report of the National Board of Health and Welfare 'Welfare and Health in Sweden 1994' [37].

Also in some other countries, health policy makers have showed or are starting to show interest in the HE indicator. In Finland, for instance, the wish to estimate HE - now fulfilled - [38] was expressed as early as 1987 in a document published by the Ministry of Social Affairs and Health as their national elaboration of 
WHO's Health For All strategy [34,35,39]. In Belgium one of the research reports describes $\mathrm{HE}$ as a tool for planning and decision making in the health care sector [40]. The Belgian presentation of results of $\mathrm{HE}$ calculations - mostly based on regional data - was amongst others followed by the approval of a plan to organize a national Health Interview Survey (Van Oyen, personal communication).

It should also be mentioned here that HE has been explicitly included in the Health for All by the year 2000 strategy that the European office of the World Health Organization formulated in 1984. Healthy life expectancy and disabilityfree life expectancy were proposed as indicators to monitor progress for two of the 38 health targets $[34,35]$.

\subsection{Provisional classification system}

Table 1 gives the distribution of HE calculations in EU member states according to the provisional classification system. Disability-free life expectancy (DFLE) and healthy life expectancy (HLE) which is based on perceived health, are the most popular categories (each calculated in nine countries). The diseasefree life expectancies all concern dementia-free life expectancy. Impairment-free life expectancy and health-adjusted life expectancies are still missing.

\section{Discussion and conclusions.}

Compared to 1989 , the year that the international researchers' network REVES started, the interest of countries of the EU in $\mathrm{HE}$ calculations has greatly increased. HE calculations have now been carried out in 11 member states and most of these countries have experience with more specific calculations like trend analysis and disease specific calculations.

Initially the concept of HE attracted the attention of researchers, followed by National Statistical Institutes. More and more, however, national (and sometimes regional) health policy makers have become interested. Not surprisingly this interest of policy makers is mostly observed in countries that were the first to come up with HE calculations. However, in some countries where respondents were not yet able to mention concrete examples of policy use, the interest of policy makers seems to be increasing.

A positive finding, from the point of view of Euro-REVES as a harmonizing activity, is that there have already been many initiatives. In many countries, experience with HE is rapidly growing. Given the similarities found in conceptual approach and in the way calculations are made - at least between a number of countries - there seems to be enough common ground to justify the hope of the perspective of future comparability in the EU. On the other hand, there is also a great diversity in concepts, approaches, sources, questions, calculations and inter- 
ests. This, however, may turn out to be a less serious problem as it doesn't make sense thinking about international comparability in terms of 'all data collections and all calculations need to be exactly the same everywhere'. It seems more realistic to pursue parsimony, thus comparability for a minimum set of items. Leaving countries the freedom to tackle their own specific problems in their own way, therefore, will enhance rather than hamper harmonization.

However, the harmonization necessary to achieve a comparable minimum set of HE calculations throughout Europe poses a great challenge to the joint efforts of policy makers, data collectors and researchers. Euro-REVES is fully aware that it can never achieve such a goal on its own. Therefore the network hopes to establish fruitful collaborations with other groups and agencies active in this field of public health epidemiology.

\section{Acknowledgements}

This text was written after papers presented at the 1st Euro-REVES meeting in Leiden (7-9 June 1995) and the 8th REVES meeting in Chicago (5-7 October 1995). We wish to thank the national teamleaders or Euro-REVES and other respondents for their kind cooperation, especially our colleagues from Belgium, Denmark, England and Wales, Finland, France, Spain and Sweden for the reports they sent us and for their comments on the draft version of this paper.

\section{References}

[1] Omran, A.R., The epidemiologic transition: a theory of the epidemiology of population change. Milbank Quarterly, 49 (1971) 509-538.

[2] Olshansky, S.J. and Ault, B., The fourth stage of the epidemiologic transition: the age of delayed degenerative diseases. Milbank Quarterly, 64(3) (1986).

[3] Water, H.P.A. Van De., The policy relevance and the further development of the health expectancy indicator. In: J.M. Robine, C.D. Mathers, M.R. Bone and I. Romieux (Eds.), Calculation of Health Expectancies: Harmonization, Consensus Achieved and Future Perspectives, Colloque INSERM, Paris/John Libbey Eurotext, London, 1993.

[4] Robine, J.M. and Ritchie, K., Healthy life expectancy: evaluation of global indicator of change in population health. British Medical Journal, 302 (1991) 457-460.

[5] Bone, M.R., International efforts to measure health expectancy. Journal of Epidemiology and Community Health, 46 (1992) 555-558.

[6] Robine, J.M., Romieux, I., Cambois, E., Water, H.P.A. van de, Boshuizen, H.C. and Jagger, C., Global Assessment in Positive Health, REVES/INSERM, Montpellier, 1995.

[7] Robine, J.M., Blanchet, M. and Dowd, E., Health Expectancy: First Workshop of the International Healthy Life Expectancy Network (REVES). OPCS Studies on Medical Population Subjects No. 54, HMSO, London, 1992.

[8] Robine, J.M., Mathers, C.D., Bone, M.R. and Romieu, I. (Eds.), Calculation of Health Expectancies: Harmonization, Consensus Achieved and Future Perspectives, Colloque INSERM, Paris/ John Libbey Eurotext, London, 1993. 
[9] Mathers, C.D., McCallum, J., Robine, J.M., (Eds.), Advances in Health Expectancies, Australian Institute of Health and Welfare AGPS, Canberra, 1994.

[10] EURO-REVES, Harmonization of Health Expectancy Calculations in Europe; Proposal to BIOMED for a Concerted Action, Euro-REVES/INSERM, Montpellier, 1992.

[11] EURO-REVES, Newsletter I, Euro-REVES/INSERM, Montpellier, January 1995.

[12] EURO-REVES, Newsletter II, Euro-REVES/INSERM, Montpellier, September 1995.

[13] Water, H.P.A. Van De and Perenboom, R.J.M., Report of the First Meeting of the Euro-REVES Subcommittee Policy Relevance and Conceptual Harmonization, Euro-REVES/TNO-PG, Leiden, 1995.

[14] Boshuizen, H.C. and Van De Water H.P.A., An International Comparison of Health Expectancies, TNO Health Research. TNO-PG, Leiden, 1994.

[15] World Health Organization (WHO), International Statistical Classification of Diseases and Related Health Problems: Tenth Revision, Vol. 1, WHO, Geneva, 1992.

[16] World Health Organization (WHO), International Classification of Impairments, Disabilities and Handicaps: A Manual of Classification Relating to the Consequences of Disease, WHO, Geneva, 1980.

[17] Brown, S.C., Aging and Disability Trends in the Third World. Center for Assessment and Demographic Studies, Gallaudet Research Institute, Washington, 1990.

[18] Egidi, V., Population ageing and changing lifestyles in Europe. Paper presented at the Seminar on Present Demographic Trends and Lifestyles in Europe, Strasbourg, 18-20 September 1990.

[19] DIKE - Dansk Institut for Klinisk Epidemiologi, Sundhedstilstand, sundhedsadfærd, forebyggelseprogram (Public Health, Health Bchaviour, Prevention Programme), DIKE, Copenhagen, 1991.

[20] Ministry Of Health, The Health Promotion Programme of the Government of Denmark, Ministry of Health, Copenhagen, 1992.

[21] DIKE - Dansk Institut for Klinisk Epidemiologi, Ideer til forebyggelse af muskel- og skeletsygdomme i Danmark (Ideas for the Prevention of Musculo-skeletal Disorders in Denmark), DIKE, Copenhagen, 1993.

[22] Bone, M.R., Bebbington, A.C., Jagger, C., Morgan, K. and Nicolaas, G., Health Expectancy and its Uses, OPCS, London, 1995.

[23] Haut Comite De La Sante Publique (High Commission on Public Health), La santé en France: rapport général (Health in France: General Report), Haut Comité de la Santé Publique, Paris, 1994.

[24] VTV - Volksgezondheid Toekomst Verkenning, De gezondheidstoestand van de Nederlandse bevolking in de periode 1950-2010 (Public Health Status and Forecasts. The State of Health of the Dutch Population in the Period 1950-2010), Sdu Publishers, Den Haag, 1993.

[25] Ruwaard, D., Kramers, P.G.M., Van Den Berg Jeths, A. and Achterberg, P.W., Public Health Status and Forecasts: The Health Status of the Dutch population over the Period 1950-2010, Sdu Publishers, The Hague, 1994.

[26] Water, H.P.A. Van De, Boshuizen, H.C. and Perenboom, R.J.M., Health Expectancy of the Dutch Population (Report No. 431501 009), RIVM/TNO-PG, Bilthoven, 1995.

[27] Water, H.P.A. Van De, Boshuizen, H.C. and Perenboom, R.J.M., Health expectancy in the Netherlands 1983-1990. European Journal of Public Health (accepted for publication).

[28] Ministerie Van Volksgezondheid, Welzijn En Sport (Ministry of Hcalth, Wclfare and Sport), Gezond en wel: het kader van het volksgezondheidsbeleid 1995-1998 (Healthy and Sound: The Framework of the Public Health Policy 1995-1998), Sdu Publishers, The Hague, 1995.

[29] Boshuizen, H.C., Van De Water, H.P.A. and Perenboom, R.J.M., Sociaal-economische verschillen in de gezonde levensverwachting (Socio-economic differences in health expectancy in the Netherlands). T. Soc. Gezondheidsz, 72 (1994) 122-127.

[30] Boshuizen, H.C., Van De Water, H.P.A. and Perenboom, R.J.M., Socio-economic differences in health expectancy in the Netherlands. In C.D. Mathers, J. McCallum and J.M. Robine (Eds)., Advances in Health Expectancies, Australian Institute of Health and Welfare AGPS, Canberra, 1994. 
[31] Departament De Sanitat I Seguretat Social (Ministry of Health and Social Security), Pla de salut de Catalunya (Health Plan for Catalonia), Departament de Sanitat i Seguretat Social, Barcelona, 1991.

[32] Departament De Sanitat I Seguretat Social (Ministry of Health and Social Security), Com millorar la salut a les regions: l'experiència de Catalunya (Working Together for Health Gain at Regional Level: The Experience of Catalonia). Paper presented at the European Health Policy Conference 'Opportunities for the Future'. Copenhagen, 5-9 December 1994

[33] Servicio Vasco De Salud; Departamento de sanidad del gobierno Vasco (Department of IIealth; Ministry of Health of the Basque Region), Plan de salud del Pais Vasco, 1994 (Health Plan for Basque Country, 1994). Servicio central de Publicaciones G.V, Vitoria-Gasteiz, 1994.

[34] World Health Organization (WHO), Targets for Health For All: Targets in Support of the European Regional Strategy for Health For All, WHO, Regional Office for Europe, Copenhagen, 1985.

[35] World Health Organization (WHO), Health For All Targets; The Health Policy for Europe, updated edition, September 1991, WHO, Regional Office for Europe, Copenhagen, 1993.

[36] Regidor, E., Rodiriguez, C. and Gutierrez-Fisac, J.L., Indicadores de salud: tercera evalución del programa regional europeo salud para todos (Health Indicators: Third Evaluation of the Health For All Programme in the European Region), Ministerio de Sanidad y Consumo, Madrid, 1996.

[37] Socialstyrelsen (The National Board of Hcalth and Welfarc), Welfare and Public Health in Sweden 1994, Socialstyrelsen, Stockholm, 1995.

[38] Valkonen, T., Sihvonen, A.P. and Lahelma, E., Disability-free life expectancy by level of education in Finland. In C.D. Mathers, J. McCallum and J.M. Robine (Eds.), Advances in Health Expectancies, Australian Institute of Health and Welfare AGPS, Canberra, 1994.

[39] Ministry Of Social Affairs and Health, Health for All by the Year 2000: The Finnish National Strategy, Ministry of Social Affairs and Health, Helsinki, 1987.

[40] Roelands, M. and Van Oyen, H., De levensverwachting zonder invaliditeit op hogere leeftijd: een methode voor planning en besluitvorming in de gezondheidssector (Life Expectancy Without Disability at Older Age: A Method for Planning and Decision Making in the Health Care Sector), Federale Diensten voor Wetenschappelijke, Technische en Culturele Aangelegenheden, Brussels, 1995. 